\title{
RADICAL ISLAMISM'S APPROACH TO THE KURDISH QUESTION IN TURKEY (1980-2002): “THE KURDISH QUESTION IS THE UMMAH'S QUESTION"*
}

\author{
Türkiye'de Radikal İslamcılığın Kürt Sorununa Yaklaşımı (1980-2002): “Kürt Sorunu \\ Ümmetin Sorunudur"
}

Arş. Gör. Dr. Abdül Samet Çelikçi

Orcid: 0000-0001-7203-9957/Muş Alparslan Üniversitesi, iktisadi ve İdari Bilimler Fakültesi, Siyaset Bilimi ve Kamu Yönetimi Bölümü.

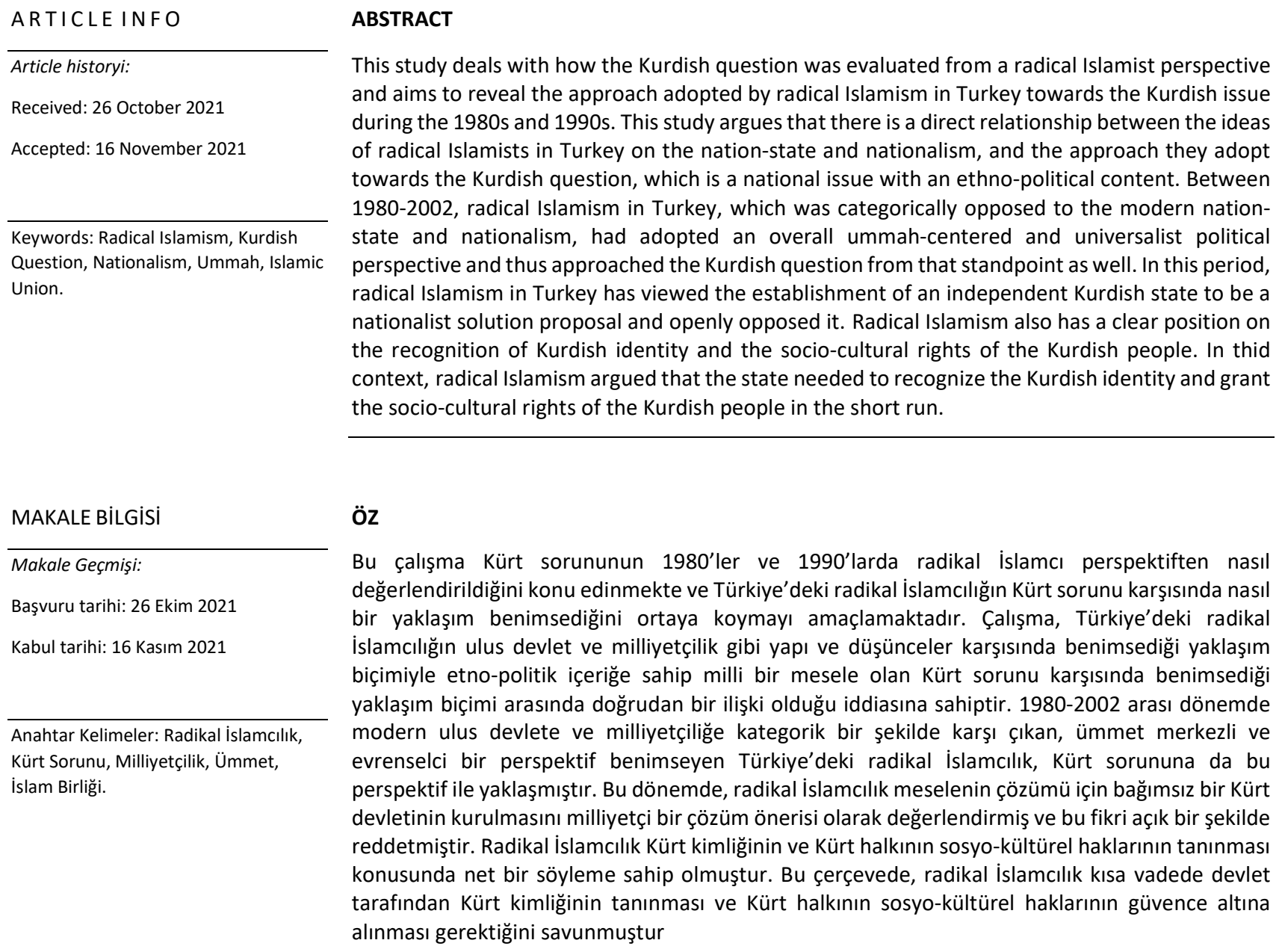

\footnotetext{
* This article is derived from the doctoral dissertation titled "The Approach Of Islamism To The Kurdish Question In Turkey (1980-2002)" prepared by Abdül Samet Çelikçi.
}

Sorumlu yazar/Corresponding author.

e-posta: sametcelikci@hotmail.com. 


\section{INTRODUCTION}

The 1980s was a milestone for the Kurdish question in Turkey. The Kurdish issue has deepened and grown in the post-1980 period and has become one of the main issues discussed in Turkish politics. Another important development during the same period has been the rise of Turkish Islamism. A radical line emerged and started to take shape in Turkish Islamism since the mid-1970s, and showed a significant vitality in Turkey's intellectual and political life during the 1980 s and especially the 1990s. It would not be wrong to say that radical Islamism ${ }^{1}$ developed an important opposition discourse in the post-1980 period with its criticisms of the established order both in Turkey and in the Islamic world. This study deals with how the Kurdish question was evaluated from a radical Islamist perspective during the 1980s and 1990s. The main purpose of the study is to reveal the approach adopted by radical Islamism in Turkey towards the Kurdish issue during the 1980s and 1990s.

There are some academic studies that deal with the issue of how Turkish Islamism approached the Kurdish problem in that period. One of these is an article titled "Kurdish Nationalism From an Islamist Perspective: The Discourses of Turkish Islamist Writers" by Ümit Cizre Sakallıoğlu. In her study, Sakallıoğlu classifies the Islamist writers who have presented their views on the Kurdish question as "Kurdish ones" and "Turkish ones" and reveals the similarities and differences between these two groups (Sakallıoğlu, 1998). Another study on the issue, written with a similar method, is an article titled "Islamism, Kurds and the Kurdish Question" by Serdar Şengül. Şengül, like Sakallığlu, makes a distinction between "Kurdish Islamists" and "non-Kurdish Islamists", thus identifying the similarities and differences between the two groups (Şengül, 2005). However, the Kurdish question is a national issue with an ethno-political content, which includes discussions such as the recognition of the Kurdish identity and the socio-cultural rights of the Kurdish people, demands for federation/autonomy and even the establishment of an independent nation-state. Therefore, this study argues that there is a direct relationship between the ideas of radical Islamists in Turkey on the nation-state and nationalism, and the approach they adopt towards the Kurdish question, which is a national issue with an ethnopolitical content. Thus, this study examines how radical Islamism in Turkey viewed, defined and engaged with the Kurdish question by situating these debates within their understanding of the nationstate and nationalism.

The first part of the study provides the historical development and basic discourses of radical Islamists in Turkey in general and more specifically, it examines their views on the nation-state and nationalism. The second part discusses how the Kurdish question entered the agenda of Turkish Islamism in the post-1980 period and then introduces the point of view of radical Islamists about the issue. The last part of the study focuses on the writings of the following leading radical Islamist figures in Turkey in the 1980s and 1990s; namely Hamza Türkmen, Ali Bulaç, Mehmet Pamak, Ercüment Özkan, Seyfettin Mut, Abdurrahman Arslan, Burhan Kavuncu, Hüseyin Okçu and Atasoy Müftüoğlu. This section discusses first how these figures interpreted the debates regarding the resolution of this problem, such as the establishment of an independent Kurdish state and the recognition of Kurdish identity and the socio-cultural rights of the Kurdish people, from their own perspectives; and then solution proposals to achieve an ultimate and permanent resolution.

\section{Historical Development and Main Discourses of Radical Islamism in Turkey}

It is possible to trace the emergence of the Islamist movement back to the second half of the 19th century in Turkey. Thus, Islamism has a history of approximately 150 years in Turkey. However, radical Islamism does not have such a long history. Until the second half of the 1970s, it is not possible to talk about the existence of a radical Islamist figure or movement in Turkey. The only exception to this situation is the Hizbu't Tahrir Movement and Ercüment Özkan, the leader of this movement in

\footnotetext{
${ }^{1}$ In this study, the concept of radical Islamism refers to the type of Islamism in which radical objections to the established order both in Turkey and in the Islamic world are expressed in an intellectual context.
} 
Turkey in the 1960s. Hizbu't Tahrir, which means Liberation Party, is a Jordanian-based party founded in 1952 by Takiyeddin an-Nabhani. Hizbu't Tahrir, which has never achieved an official status, advocates the idea that Muslims must unite and establish an "Islamic state based on the caliphate" (Erkilet, 2015: 157-159). Due to a number of factors, a radical wing within Turkish Islamism emerged and started to take shape since the mid-1970s, and became very active intellectually through large numbers of popular publications in Turkey during the 1980s and especially the 1990s. The factor deemed to be the most influential in the emergence of radical Islamism in Turkey is the translations of Islamists' works from around the Muslim world into Turkish which began in the second half of the 1960s. During this period, especially Sayyid Qutb, who became the ideologue of the Egyptian-based Muslim Brotherhood in the 1950s and 1960s, and Abu al-A'al al-Mawdudi, the founder of the IndiaPakistan-based Jama'at-i Islami stands out as the two most influential figures on radical Islamism in Turkey through the translations of their some of their works into Turkish (Bora, 2017: 456). It would not be wrong to say that Qutb's conceptualizations of the jahiliyya and hakimiyyah and Mawdudi's Islamic State have had a major impact on radical Islamism in Turkey. In addition, works of Ali Shariati, Fathi Yakan and Sa'id Hauwa have also been translated. Influenced by these translated works, radical Islamist figures and movements in Turkey started to discuss concepts such as "Dar al-Harb/Dar alIslam, jihad, tag, evil Hijra, bay'ah" (Şentürk, 2011: 461) and thus began to raise deep-rooted criticism to the existing system. Another factor that had an impact on radical Islamism in Turkey during this period was the Iranian Islamic Revolution that took place in 1979. The revolution in Iran created great excitement in Turkey, as it did in other countries in the Islamic world. The realization of this revolution led to the formation of the idea that Islam is an alternative, apart from the existing bipolar liberal and leftist framework, in Islamist circles (Koyuncu, 2018: 103).

The interrelated debates on globalization and postmodernism, and concurrent rise of identity politics was another factor that enabled radical Islamism to develop in the 1980s and especially in the 1990 s and to display significant vitality intellectually and to employ vigorous program of publications in Turkey. As a matter of fact, the 1990s, the period following the end of the Cold War, was marked by not only the rise of Islamism, but also criticisms of modernity in general and identity politics, with claims of "authenticity" in particular all over the world (Gülalp, 2003: 9). During this period, the acceleration of globalization has led to the fragmentation of existing national identities, as well as the rise of ethnic and religious sub-national identities, so Islamism has come to the fore as an alternative source of identity more so than in previous periods (Koyuncu, 2018: 105). The 1990s, also referred to as the "postmodern period", was also a time when "modernism was questioned, 'authenticity' was defended instead of the identities and cultures put forward by modernism, and cultural resources known as 'traditional' were reactivated in the name of diversity" (Gülalp, 2003: 116). The crisis of modernism that emerged during this period created quite favorable conditions for Islamist critique (Gülalp, 2003: 133). In other words, the radical postmodernist critiques of modernism provided an important opportunity for Islamism and Islamists benefited from postmodernist literature extensively in this period (Koyuncu, 2018: 105). Radical Islamists offered a critical analysis of Western modernity and tried to envision an alternative to modernity during the 1980s and 1990s (Göle, 2008: 54). Radical Islamism adopted an anti-modern stance in this process to create an alternative Islamic model and embarked on "a large-scale inquiry on consumption, corruption, nationalism and corruption", which it saw as the "sinful by-products" of Western modernization and civilization (Göle, 2008: 107).

İsmet Özel is one of the most prominent thinkers among those who has offered a radical Islamist critique of the West and modernity. Özel, rejecting Ziya Gökalp's civilization-culture distinction in his work titled "Three Matters: Technology-Civilization-Alienation", first published in 1978, rejected not only Islamists' analysis of modernity, but also all other ideologies heretofore present in Turkey (Bora, 2017: 451). According to Özel, being despondent in the face of the technical power of the West is a disease that became widespread especially during the times when Western civilization oppressed Islamic countries and still occupies the minds of Muslims. This intimidation has led many thinkers to 
adopt technology, which is the basis of the material power of the West, as a way out, while staying away from its moral and intellectual values. However, this approach shows that the issue is not understood at all (Özel, 2019: 95). For Özel, to expect that Islamic values will coexist with the scientific and technical mind of the age is false consolation because "the science and technology that is currently dominant is the extension of a worldview that has emerged during a certain period in the West", and "has developed within the context a certain social structure, and has expanded its power on a world scale by a social class whose characteristics are diametrically opposed to Islam". In other words, according to Özel, the point that Muslims need to realize is that "the West is the totality of its belief, philosophy, science and technology, and if it is to be rejected, it will have to be rejected totally, or if it is to be accepted, it will have to be accepted completely". Therefore, it is not possible for Muslims to "reject those institutions and adapt the technological and scientific structure that is the product of those institutions" into their lives (Özel, 2019: 95-96). It should be noted also that an important medium in which the radical Islamist critiques of the West and modernity manifests itself is the journal Bilgi ve Hikmet, published between 1993 and 1995 by Ali Bulaç and Abdurrahman Arslan.

Along with its deep-rooted critiques of the West and modernity, radical Islamism in Turkey, which started to move away from the Turkish right wing political tradition towards the end of the 1970s, categorically opposed and refused to adopt the existing structures, ideas and conceptualizations of the nation-state, nationalism and national identity. Radical Islamist ideologues and movements argued that these structures, ideas and concepts in question were not only in harmony with Islam and its political and social vision, but also incompatible. In other words, according to radical Islamists, there is a doctrinal incompatibility between the socio-political order that is envisaged by Islam and is based on nationalism and the nation-state. Accordingly, for radical Islamists, the salvation of Turkey, and indeed the entire Islamic world, from the problematic situation is only possible by establishing an Islamic State, building a community of ummah, and finally realizing the İttihad-I Islam (Islamic Union).

In the ideas put forward by radical Islamists, there is no distinction between positive and negative nationalism, which is widely seen in the mainstream line of Turkish Islamism. Radical Islamists' categorical opposition to nationalism is due to their view of nationalism and Islam as being doctrinally incompatible as previously stated. For them, the main reason for this incompatibility and contradiction is that nationalism is a divisive ideology that is both Western and secular, therefore foreign to the Islamic world and has ethnocentric features. On the other hand, Islam, with its universality and understanding of the ummah, is an all-encompassing and unifying characteristic that transcends ethnicities. As will be shown in the following sections of the study, this view of radical Islamism to nationalism and the nation-state in Turkey has also been the main underlying framework for its approach to the Kurdish question.

\section{Radical Islamism and the Kurdish Question in the Post-1980 Era}

The Kurdish Question, as expressed in the introduction of the study, is fundamentally an ethnopolitical problem that includes issues such as the recognition of Kurdish identity, the granting of cultural rights such as speaking, writing, education and broadcasting in the Kurdish mother tongue, calls for federation/autonomy and an independent nation-state. Although Turkish Islamism's engagement with the Kurdish Question can be traced back to the 1960s, the issue was not heavily discussed by Islamists until the second half of the 1970s with the gradual development of Kurdish nationalism and the increase in the number and activities of independent Kurdish organizations. It is possible to say that after the mid-1970s, Islamist circles started to address the issue more. ${ }^{2}$ However, it is clear from the debates carried out in the pre-1980 period that Turkish Islamists did not consider

\footnotetext{
${ }^{2}$ For a study dealing with the approach of the Turkish right including Islamism to the Kurdish question in the pre1980 period, see (Koca, 2021),
} 
the issue as an ethno-political problem, and therefore did not use the term Kurdish Question in their writings.

After the mid-1980s, some Turkish Islamists started to discuss the issue as a problem with an ethno-political content and to label it the Kurdish Question. Several factors underly this change. First of all, the increasing terrorist attacks of the PKK that had started in 1984 had made the problem more visible, the Kurdish Question emerged as one of the main problems in Turkish politics and started to be discussed not only by Islamists, but also by large sections of the public. However, there is another factor that played a triggering role, though not directly, in the Turkish Islamism's re-discussion of the issue as a Kurdish issue in the post-1980 period. This factor is the Anfal Campaign carried out by the Iraqi army against the Kurds of Northern Iraq between 1986 and 1988 and the Halabja Massacre on March 16, 1988, with the use chemical gas as part of the offensive. The Iraqi army's targeting of the Kurds of Northern Iraq not only caused the death of thousands of people, but also created a very serious wave of migration. In this process, many Kurdish refugees came to Turkey and refugee camps were established in certain regions in Turkey. These developments certainly provoked Islamists, who had already started to address the Kurdish question, to become more vocal about it.

It would not be wrong to say that the journal Girişim was at the forefront of the Islamist media where the Kurdish issue was addressed in the second half of the 1980s. Along with covering the Kurdish question in Turkey in many issues, the magazine also frequently addressed the conditions of the Kurds of Northern Iraq, who experienced serious tragedies and had to take refuge in Turkey. ${ }^{3}$ Since the late 1980s and throughout the 1990s, when the Kurdish question became on the top problems in Turkey, every segment of Turkish Islamism was discussing the issue on various platforms.

The mainstream Islamists in Turkey have historically argued that "the established order" since the founding of the Republic has been the problem, and accordingly have understood the Kurdish question as a problem caused by the established order and official ideology of Turkey. However, radical Islamists while agreeing with this view to a certain extent, adopted a broader perspective based on an ummah-centered vision towards the problem. Thus, for radical Islamists, the Kurdish question is part of a larger problem that includes the problem of the established order of Turkey; namely the Ummah problem. Accordingly, the Islamic world was introduced to the ideology of Western nationalism in the middle of the 19th century, and at the beginning of the 20th century, it was shattered by being integrated into the nation-state system, and as a result, the Islamic Ummah was divided into nations. There are cruel and collaborative governments at the head of the states in question, and these governments inflict great atrocities on the already divided Islamic ummah in different countries. In other words, the current situation of the Islamic world and its ummah is like a chain of problems, a tangle of problems. Thus, it is possible to state based on this view that radical Islamists see the Kurdish question as a part of the problem of the Ummah facing the Islamic world and define it as a problem of the Ummah. In this respect, for radical Islamists, the main source of the problem is not only the establishment and official ideology of Turkey, but also the nation-state system on which the establishment in Turkey is based, that is, the existence of nationalism and nation-states themselves. As will be seen in the next section, this understanding defines the perspective of radical Islamism in the discussions that came to the fore within the scope of the solution of the Kurdish question in the post-1980 period.

\footnotetext{
${ }^{3}$ For some examples of the articles in Girişim between 1985-1990, in which the Kurdish question in general and the situation of Kurdish refugees who came to Turkey after the Halabja massacre were evaluated in particular, see (Çamurcu ve Günel, 1987: 8-19; (Okçu, 1988: 24-26); (Aydın, 1988: 4-16); (Aydın, 1988: 6-7); (Öcal, 1989: 4649); (Girişim, 1990: 20-27); (Derviş, 1990: 34-36). Also, in this period, Sheikh Said Rebellion was covered in some issues of the journal. It is seen that the issue is described as a "resurrection" in the journal. For a sample article, see (Okçu, 1989: 4-17).
} 


\section{Radical Islamists' Solution to the Kurdish Question}

This section discusses the debates with regards to the peaceful resolution of the Kurdish question in Turkey in the post-1980 period under two headings and provides the radical Islamists perspectives for each. First sub-section addresses the debates on the establishment of an independent Kurdish state. The second interrogates the debates involving the recognition of the Kurdish identity and the socio-cultural rights of the Kurdish people and the resolution proposals to end the conflict.

\section{Debates on an Independent Kurdish State}

In the post-1980 period, with the rise of the Kurdish Question to the top of Turkey's agenda, one of the main topics of discussion with regards to the resolution of the problem was the establishment of an independent Kurdish state including the Eastern and Southeastern regions of Turkey.

As previously stated, radical Islamists in Turkey have been categorically in opposition to nationalism and the nation-state and have adopted an ummah-centered vision. Reflecting this vision, radical Islamist figures and movements have clearly opposed the idea of an independent Kurdish state as a possible solution of the Kurdish problem because of its nationalist character. According to radical Islamists, the root of the Kurdish question is nationalism anyway, so nationalist means of resolution are by no means acceptable. As will be shown in the following, radical Islamists oppose the idea of a nation-state not only for Kurds, but also for Turks, Arabs or Persians, as a reflection of a categorical opposition.

For example, according to Hamza Türkmen, the PKK aims first to obtain a federal or autonomous status for the Kurdish people, and then establish a nation-state. In this respect, the path followed by the PKK is no different from the path of Kemalism because the PKK is trying to harm the bond of the ummah and Islamic values by spreading nationalism among the Kurdish people. However, "the resolution of the Kurdish question by the nation-states in the region and the nationalist Kurdish reaction will be unnatural and unjust" (Türkmen, 1997: 46). Based on his strong rejection of the nationalistic solutions of the Kurdish question, Türkmen is a staunch opponent of the proposition for establishing an independent Kurdish nation-state. He posits that tough the region Kurdish people inhabit is called "Kurdistan", the term should not be considered to refer to a nation-state because nationalism, like liberalism, socialism and secularism, is one of the "ignorant" emotions and attitudes that cloud Islamic identity. Therefore, both "Turkey-ism" and "Kurdistan-ism", are nationalisms, based on national identity, thus both are "jahiliyye" (ignorance). Türkmen states that it is possible for Muslims to reach the understanding of Islamic unity, not by producing national borders, but only by surpassing them (Türkmen, 1997: 50). ${ }^{4}$

Ali Bulaç argues that ultimately the ethnic identity of a community is "ontological materialism", thus nationalism that overlaps with ethnic identity means the "self-worship" of a community. For this reason, he states that nationalism, which envisages the glorification of ethnic identity and nation, is unacceptable from an Islamic point of view (Bulaç, 1992: 36). Consequently, Bulaç also opposes the idea of an independent Kurdish state. He believes it is not possible to resolve the Kurdish question by a nation-state since the nation-state is at the root of the Kurdish people's problems. Therefore, the idea that existing problems can be solved by establishing a new nation-state would mean insisting on repeating a mistake (Bulaç, 1992: 36-37). Bulaç emphasizes that the Kurdish people are an indispensable part of the Islamic Ummah, their destiny and interests depend on the fate and interests of other Muslims, and in this context, their salvation depends on Islam (Bulaç, 1992: 38).

\footnotetext{
${ }^{4}$ For an article written by Hamza Türkmen and expressing similar views on the issue, see (Türkmen, 1993: 4-6). Also, for another article in the journal Dünya ve İslam, published by Türkmen between 1990-1993, in which it was stated that nationalism would not be a solution to the Kurdish question, see (Aksu, 1991: 11-22).
} 
Mehmet Pamak is another figure who views nationalist solutions to the Kurdish question as unacceptable. According to Pamak, "whichever justification or provocation and pressure it is based on, kavmiyetçilik (tribalism) should be considered as a dangerous, harmful scourge that will lead people out of Islam and rejected" (Pamak, 1992: 280). According to Pamak, paying close attention to the Kurdish question and being in favor of the legitimate rights of the Kurdish people is not the same as wanting an independent Kurdish state. Thus, Pamak, like other radical Islamist figures, opposes the idea of establishing an independent Kurdish state and states that it is not possible for a Muslim to defend the idea of a nation-state and work for it. In addition, he argues that the nation-state of Turkey should similarly be opposed by all Muslims at this point. For him, the rejection of the Turkish nationstate to the same degree as the Kurdish nation-state is in accordance with the beliefs of Muslims (Pamak, 1992: 295)

Ercüment Özkan also clearly opposes the idea of establishing an independent Kurdish state nationalism as a solution to the Kurdish question. According to Özkan, Muslim societies such as Turks, Arabs and Albanians have founded nation-states and could not find what they expected. Thus, the establishment of an independent Kurdish state will not solve anything and will mean repeating the same mistake (Özkan, 1991: 7). He argues that Muslims should be in favor of a state named after Islam, not named after different races. For Özkan, trying to establish another nation-state has no place in Islam. Instead, what needs to be done is to strive to transform the current state into an Islamic one (Özkan, 1992: 223). Seyfettin Mut, another Islamist figure, also is of the opinion that it is not possible to solve the Kurdish question by establishing a state. Overcoming nationalism is possible not by turning a new community into a nation, but by trying to change the existing nation-state structures (Mut, 1996: 15).

Abdurrahman Arslan states that the solution of the Kurdish question should not be sought on the basis of the nation state because the nation-state is being discussed intensively and unlikely to survive under the current postmodern conditions. Furthermore, according to Arslan, Islam is against the nation-state and racist state anyway. For this reason, Muslims should consider a new social model for the future and should not be organized as a nation-state. On the contrary, Arslan says that Muslims, whose ultimate goal is to form an ummah, should reject both the conceptual model and the organizational form of the nation-state (Arslan, 1996: 90-91). Burhan Kavuncu also strongly opposes nationalist solutions to the issue. According to Kavuncu, the political polarization in the region is between the "secular Turkish Republic" and the "secular PKK". The oppressed Kurdish people, on the other hand, are caught between two "oppressive, nationalist and secular" fires (Kavuncu, 1992: 163). Nevertheless, nationalisms targeting the oppressor's ethnic identity and life will not bring "liberation" (Kavuncu, 1992: 158).

\section{Debates on the Recognition of Kurdish Identity and Socio-Cultural Rights of the Kurdish People and Proposals to Achieve a Lasting Resolution}

Through the discussions on the establishment of an independent Kurdish state, the article has so far shown what radical Islamist in Turkey did not accept as a solution of the Kurdish question. In the post-1980 period and especially during the 1990s, recognition of Kurdish identity, constitutional guarantees of the socio-cultural rights of the Kurdish people, and ultimate resolution of the issue have been at the forefront of the debates on solutions to the Kurdish question.

Radical Islamist figures and movements in Turkey stated that the Islamic world including Turkey is facing an ummah question, and that the Islamic world's salvation from this challenging situation can only be achieved by establishing an Islamic state and building a community of ummah. It is possible to state that this ummah-centered perspective was constitutive of radical Islamists' solutions to the Kurdish issue in the 1980s and 1990s. Radical Islamists, who saw the Kurdish question as a part of the ummah question and rejected nationalist proposals for a solution, argued that a real resolution of the former would be possible by the resolution of the latter. According to this view, the 
ultimate lasting solution to the issue could only be possible through a union, namely the Union of Islam, where the identity of every tribe of the ummah would be recognized and preserved. This union would be realized through a long-term struggle based on commitment to the ummah (or ummah consciousness).

The fact that for radical Islamists the complete and permanent resolution of the issue could only be achieved in the long term did not trivialize the recognition of Kurdish identity and the sociocultural rights of the Kurdish people. On the contrary, it is possible to state that radical Islamists had a clearer vision of and took a firm stand on the recognition of Kurdish identity and the socio-cultural rights of Kurdish people during the 1980s and 1990s. According to radical Islamists, Allah has created all tribes as equal and none is superior than the other. Therefore, all tribes having equal rights is actually a requirement of Islam. In this framework, in the short term, together with all other tribes, the Kurdish identity should be recognized by the state and all socio-cultural rights of the Kurdish people should be guaranteed.

Hamza Türkmen states that the Kurdish question is ummah's question and argues that the resolution of the former is intertwined with the resolution of the latter (Türkmen, 1997: 50). According to Turkmen, unless the right vision and struggle to revive the ummah is not initiated, and the political currents, identities and oppression in the region based on nationalism are not broken, it will not be possible to resolve the Kurdish. Because he argues, the national solutions constitute the problem, as can be observed in the Arab, Kurdish and Persian nationalist movements in the region (Türkmen, 1997: 50).

Turkmen states that from a revelation perspective, it is absolutely out of question for a responsible Muslim to remain indifferent to the Kurdish issue. Dealing with the issue means, first of all, seeing the Kurdish reality (Türkmen, 1997: 49). According to the Turkmen, like all other peoples, the Kurdish people should preserve their legitimate customs and traditions, ethnic characteristics and language with equal rights and as a sub-identity within the ummah (Türkmen, 1997: 50). On the other hand, in order to solve the Kurdish question, Muslims must inform and warn the public in order to stop the mutual bloodshed caused by the state and the PKK terrorism. In addition, it should be emphasized by Muslims that efforts to separate Turkish and Kurdish identities to determine them as primary identities will lead to the elimination of existing commonalities and that this will only benefit the enemies of Islam and imperialism. Moreover, the practices and legal violations of the official ideology that have been going on for 70 years in the region, the backwardness of the region, the interventions made on the local names and the people's ethnic identity should be highlighted, criticized and questioned (Türkmen, 1997: 50). ${ }^{5}$

According to Ali Bulaç, the Islamic world is going through a deep shock. The only and correct way to overcome this situation is Islam. As in the past, there is no other way out than to return to Islam, the glue that holds us together which is the religious brotherhood and the unity of the ummah (Bulaç, 1992: 108-109). Within this framework, Bulaç offers a two-stage solution to the Kurdish question. First, the issue that needs to be brought to public attention and resolved in the short term and urgently is the recognition of the Kurdish identity. Thus, steps such as lifting the current bans, enabling the use of Kurdish in daily life, education and in the media, restore Kurdish place names, stopping the policies of oppression, violence and deportation, and putting an end to the economic backwardness of the region should be taken (Bulaç, 1992: 36-37).

For Bulaç, it is necessary to correctly determine some basic principles as the starting point to develop long term, genuine, universal and truly Islamic solutions to the Kurdish problem. Accordingly,

\footnotetext{
${ }^{5}$ For another article in Dünya ve Islam, in which it is stated that nationalist solutions to the Kurdish question are rejected and that efforts should be made for the "Unity of the Islamic Ummah" for the final solution of the issue, see (Dünya ve İslam, 1992: 7-20).
} 
first of all, all solutions to the issue should be based on an authentic and divine reference such as the Qur'an and Sunnah. In addition, the solutions produced should be universal as well as Islamic that should be capable of solving the problems of the humankind outside the Muslim world (Bulaç, 1992: 103-104). Thus; for Bulaç, the long-term solution to the Kurdish question is through a comprehensive "İslam Birliği" (Union of Islam). It is also possible to call it "ittihad-I İslam" (Islamic Union) or "Ittihad-I Anasır-I İslam" (Unity of the Elements of Islam) (Bulaç, 1992: 38). Bulaç lists the basic principles of the union he envisions as follows:

\begin{abstract}
"Respect for the unique beauties, customs, traditions and language of each tribe. A multi-ethnic and multi-cultural social organization model where every tribe can speak their own language comfortably. Local and decentralized government with broad powers. Transition to a form of self-government or federal state system based on the natural and historical boundaries of each tribe and region. Realization of the ideal of voluntary partnership, equal participation and creation of Islamic unity. Individuals from every ethnic group demanding the same rights they would like to have for their Muslim brethren from other ethnic groups and working until these rights are achieved." (Bulaç, 1992: 38)
\end{abstract}

In other words, in Bulaç's opinion, the long-term resolution of the issue can be achieved by a "pluralist model, on the basis of equal and voluntary partnership, where everyone speaks their mother tongue comfortably, receives education in their mother tongue, and freely expresses their ethnic identity" (Bulaç, 1992: 105-106). Bulaç states that the most striking example of the model in question, which can be a solution for all the problems of the peoples of the region, including the Kurdish problem, is the famous "Medine Vesikası" (Constitution of Medina), which the Prophet of Islam signed jointly with Muslims, Jews and polytheistic Arabs after the migration. According to Bulaç, "neither historical forms of practice nor any solution type adopted from the West can be more realistic, fair, pluralistic and participatory than this document" (Bulaç, 1992: 106).

Hüseyin Okçu views the issue from the perspective of "The problem of the Kurds is the problem of the Ummah" and argues that the problems of the Kurdish people can only be solved with an Islamic approach (Okçu, 1992: 192). According to Okçu, Islamic thought is superior because the solution brought by Islam covers all nations, not any specific nation. That is, this solution guarantees the existence of not only tribes belonging to the Islamic Ummah, but also non-Muslim tribes (Okçu, 1992: 197). Okçu states that in the ummah of Islam, everyone can speak their own language, live according to their own customs and receive education in the language they choose, and this is true not only for Muslim tribes but also for non-Muslim tribes (Okçu, 1992: 196).

Mehmet Pamak argues, on the one hand, that equality of Turks and Kurds should be ensured and all legitimate rights of the Kurdish people should be given. On the other hand, he maintains that Turkish and Kurdish racism must be trampled on in order to resolve the Kurdish issue in a definitive and just way, and for this, the Islamic brotherhood must be developed within the framework of ummah consciousness. The spread and rooting of the ummah consciousness is only possible if the pain of the Kurdish people, which is a part of the ummah, is felt and shared by other parts (Pamak, 1992: 299300).

Burhan Kavuncu states that the right to be a nation, having a national consciousness and identity are among the natural rights of people, and defending these is an "Islamic obligation", and to oppose them means "opposing Allah and His Sunnah" (Kavuncu, 1992: 153). According to Kavuncu, the resolution of the Kurdish question is only possible with a universal Islamic perspective, method and struggle (Kavuncu, 1992: 158-159). He states that in order to resolve the Kurdish issue in an Islamic way, first of all, Muslims should free themselves from the effects of the racial discriminationassimilation policies imposed by the current regime in Turkey in all areas of social life, and the practices that deny the existence of and criminalize different languages and cultures "in light of the Islamic ummah consciousness" (Kavuncu, 1991: 11). 
According to Seyfettin Mut, the real solution is to first eliminate the nationalist, racist and dominating structures of the existing states, and then entering into larger-scale regional integration. Mut states that against the "imperialist" theory known as "the self-determination right of nations", the thesis of Muslims should be "the integration of Muslim peoples within a free, common and just state of law" (Mut, 1996: 15). According to Mut, the resolution to the Kurdish question is possible by "a free and fair Islamic state governed by law that recognizes the basic rights of the Kurdish people, recognizes their rights of language, culture, education, etc., expands the possibilities of decentralization through local government reform. Only such an Islamic government can eliminate the basis of nationalism and create a model that can solve not only the Kurdish problem but also the problems of all Middle Eastern peoples (Mut, 1996: 15).

Atasoy Müftüoğlu states that an Islamic approach should be adopted to resolve the Kurdish question because, according to Islam, ethnic communities are a part of universal existence and Islam unifies them within a poem of tawhid (divine oneness). Within this unity, different languages, cultures and folklore can be used without contradicting principle of tahwid (oneness of God) (Muftüoğlu, 1992: 207). According to Müftüoğlu, Muslims should know that no race or people in the world are privileged, that Islam does not favor any people or any race in particular, and it only favors people of taqwa (having God consciousness) and should not engage in any discrimination. In this way, Muslims can be more sensitive about the hostilities between the two peoples and strengthen solidarity with more intense relations (Muftüoğlu, 1992: 208). Müftüoğlu posits that Muslims should be extremely careful towards the tribal-centric understanding of history, culture and thought, emphasize the features of the universal structure of Islam, and be in constant communication in order not to turn ethnic differences into conflict, tension and hostility (Müftüoğlu, 1996: 116).

According to Abdurrahman Arslan, Muslims make their identity choices neither with the values of the nation-state nor with the values imposed on them by the modern world. Muslims look at history, geography, time and space as much as possible through the eyes of religion (Arslan, 1996: 88). This perspective is decisive in Arslan's approach toward the Kurdish question. On the one hand, he states that all Muslims have the right to express what they believe in their own language and that this is the responsibility brought by Islam, and that the cultural rights of the Kurdish people should be recognized. On the other hand, he argues Turks and Kurds, who are Muslim brothers, should seek the solution to the Kurdish question within the Ummah, which is the social model envisaged by Islam (Arslan, 1996: 91-92).

Considering the general approach of radical Islamist figures in Turkey to the Kurdish issue, it is possible to state that they show interest in the issue, but have some handicaps in finding a resolution to the question. In fact, it seems understandable that radical Islamists oppose the idea of establishing an independent Kurdish state, which is one of the proposals for the resolution of the Kurdish question. Because, as stated before, radical Islamism categorically opposes nationalism and the nation-state.

However, it can be said that the ideas of radical Islamists on the lasting resolution of the Kurdish question have some handicaps. For example, radical Islamists argue that the Kurdish identity and the socio-cultural rights of the Kurdish people should be recognized by the state. But, they think that the lasting resolution of the question can be achieved in the long term and with the resolution of the problem of the Ummah. This is due to the radical Islamists' understanding of "solving everything with Islam". This understanding, which is especially reflected in the issue of the lasting resolution of the Kurdish question, seems to prevent radical Islamists from putting forward more realistic and concrete solutions for the the Kurdish question, or cause them to move away from existing solution proposals.

\section{CONCLUSION}

In the post-1980 period, radical Islamists' views on the political structure of the nation-state and the nationalist ideology have determined their approach towards the Kurdish question, one of the 
main issues Turkey has been facing with an ethno-political basis. In other words, the most fundamental factor determining the approach of radical Islamism to the Kurdish issue in Turkey during the 1980s and 1990s was its perspective on the nation-state and nationalism. Radical Islamism in Turkey, which was categorically opposed to the modern nation-state and nationalism, had adopted an overall ummah-centered and universalist political perspective and thus approached the Kurdish question from that standpoint as well. Accordingly, the issues of establishing an independent Kurdish state, the recognition of the Kurdish identity and the socio-cultural rights of the Kurdish people, and a complete and permanent solution to the conflict were also discussed with the aforementioned ummah-centered and universalist perspective.

Radical Islamism in Turkey has viewed the establishment of an independent Kurdish state to be a nationalist solution proposal, therefore has deemed it unacceptable and openly opposed it. However, it is noteworthy that in their writings on the issue, radical Islamists particularly emphasized that they are categorically opposed not only to an independent Kurdish state, but also to the nationstate model.

Radical Islamism also has a clear position on the recognition of Kurdish identity and the sociocultural rights of the Kurdish people. It is possible to state that the reason for this is the idea of tribal/national equality that accompanies the ummah-centered and universalist perspective of radical Islamism. Accordingly, Allah has created all nations and tribes as equal and none has superiority over the other. Therefore, ensuring tribal/national equality is required by Islam. Accordingly, radical Islamist in Turkey argued that although a complete and permanent solution to the Kurdish issue is possible only in the long run, the state needed to recognize the Kurdish identity and grant the socio-cultural rights of the Kurdish people unconditionally in the short run.

However, it is clear that radical Islamism does not find reforming the established order and changing the official ideology in Turkey sufficient for a complete and permanent resolution to the Kurdish question. Radical Islamists see the Kurdish question as a part of the ummah question and thus argue that the resolution of the former will be possible by the resolution of the latter. According to this view, a complete and permanent solution should be based on a model of unity in which each tribe belonging to the Islamic Ummah can preserve its own identity instead of the existing nation-state system based on nationalism. Therefore, from a radical Islamist perspective, the path to achieve a complete and permanent resolution to the Kurdish question involves a long-term struggle consciousness of the Ummah in the long term, and in this way, the establishment of a unity, namely the Islamic Union, in which the identity of every tribe of the Ummah will be recognized and preserved.

\section{REFERENCES}

Aksu, i. (1991). Kürt Meselesi ve Ulusçuluk Üzerine. Dünya ve İslam, 7, 11-22.

Arslan, A. (1996). Kürt Sorunu Nasıl Çözülür, Haz. Nûbihar Yayınları. İstanbul: Nûbihar Yayınları.

Aydın, M. (1988). Irak'ta Kürt soykırımı ve Bir ‘Uzun Yürüyüş'. Girişim, 37, 4-16.

Aydın, M. (1988). Kürt Mülteciler Zor Durumda. Girişim, 38, 6-7.

Bora, T. (2017). Cereyanlar: Türkiye'de Siyasî Ideolojiler. İstanbul: illetişim Yayınları.

Bulaç, A. (1992). İslami Bir Perspektiften Kürt Sorunu. Kürd Soruşturması, Ankara: Sor Yayıncılık, s. 89-110.

Bulaç, A. (1992). Kürt Sorunu ile Kafkasya ve Balkanlardaki Etnik Çatışmaların Mukayesesi. Mazlum-Der Kürd Sorunu Forumu, Ankara: Sor Yayıncilık, 25-38.

Cizre Sakallıoğlu, Ü. (1998). Kurdish Nationalism From an Islamist Perspective: The Discourses of Turkish Islamist Writers. Journal of Muslim Minority Affairs, 18(1), 73-89.

Çamurcu, K. \& Günel, N. (1987). Güneydoğu Olayları. Girişim, 19, 8-19.

Derviş, M. (1990). Güneydoğu Alev Alev. Girişim, 55, 34-36. 
Dünya ve İslam (1992). Kürt Sorunu-Türk Sorunu ve Müslümanlar. Dünya ve İslam, 9, 7-20.

Erkilet, A. (2015). Orta Doğu'da Modernleşme ve İslami Hareketler. İstanbul: Büyüyenay Yayınları.

Girişim (1990). Yakın Tarih Kürt Hareketleri ve Milliyetçi Eğilimler. Girişim, 53, 20-27.

Göle, N. (2008). Melez Desenler: İslam ve Modernlik Üzerine. İstanbul: Metis Yayınları.

Gülalp, H. (2003). Kimlikler Siyaseti: Türkiye'de Siyasal İslam'ın Temelleri. İstanbul: Metis Yayınları.

Kavuncu, B. (1991). Ulusal Soruna Bakışlar: Cahili Duygulardan Arınalım. Yeryüzü, 13, 10-11.

Kavuncu, B. (1992). Kürd Soruşturması, Haz. Sor Yayıncılık. Ankara: Sor Yayıncılık.

Koca, B. (2021). "Kürtler Aslında...": Uç Sağın Kürtlere Bakışı. İstanbul: İletişim Yayınları.

Koyuncu, A. A. (2018). İslâmcılık ve Demokrasi. İstanbul: Pınar Yayınları.

Mut, S. (1996). Kürt Sorunu: Hala Vakit Var. Değişim, 39, 14-16.

Müftüoğlu, A. (1992). Kürd Sorunu Üzerine Genel Bir Değerlendirme. Mazlum-Der Kürt Sorunu Forumu. Ankara: Sor Yayıncılık, 205-208.

Müftüoğlu, A. (1996). Kürt Sorunu Nasıl Çözülür, Haz. Nûbihar Yayınları. İstanbul: Nûbihar Yayınları.

Okçu, H. (1988). Kürtlerin Sorunu Ümmetin Sorunudur. Girişim, 37, 24-26.

Okçu, H. (1989). Şeyh Said Kıyamı. Girişim, 47, 4-17.

Okçu, H. (1992). Kürtlerin Sorunu Ümmetin Sorunudur. Kürd Soruşturması. Ankara: Sor Yayıncılık, 191-200.

Öcal, H. (1989). PKK ve Doğuda Son Gelişmeler. Girişim, 48, 46-49.

Özel, İ. (2019). Üç Zor Mesele: Teknik-Medeniyet-Yabancılaşma. İstanbul: TiYY Yayıncılık.

Özkan, E. (1991). Kürdistan mı Kuruluyor Yoksa!. Iktibas, 149, 5-8.

Özkan, E. (1992). İslam ve İnsanlar. Mazlum-Der Kürt Sorunu Forumu. Ankara: Sor Yayıncılık, 219-224.

Pamak, M. (1992). Kürt Sorunu ve Müslümanlar (Özeleştiri). Mazlum-Der Kürt Sorunu Forumu. Ankara: Sor Yayıncılık, 275-302.

Şengül, S. (2005). İslâmcılık, Kürtler ve Kürt Sorunu. Modern Türkiye’de Siyasi Düşünce Cilt 6: İslamcılık. Ed. Yasin Aktay. İstanbul: İletişim Yayınları, 525-543.

Şentürk, H. (2011). İslamcılık: Türkiye'de İslami Oluşumlar ve Siyaset. İstanbul: Çıra Yayınları.

Türkmen, H. (1993). Kürt Sorunu ve Müslümanların Safı. Haksöz, 32, 4-6.

Türkmen, H. (1997). Kürt Sorunu'na Çözüm Arayışları ve İslami Tavır. Haksöz, 78, 41-50. 